\title{
Medieval Treaties and the Diplomatic Aesthetic
}

\section{Jessica Berenbeim}

\section{Diplomacy and textual objects}

This essay brings two strands of scholarship into conversation with one another: the New Diplomatic History and the study of material texts as visual culture. What follows examines a significant point of contact for these two discussions: the documents of diplomacy, and more specifically, treaty ratifications of the later Middle Ages. A central premise of New Diplomatic History involves an understanding of diplomacy as an expanded field - in other words, there is more to diplomacy than treaties. ${ }^{1}$ As this analysis will suggest, there is also more to treaties themselves. Letters of procuration, articles of agreement, and treaty ratifications all have allusive and symbolic elements, and even these most canonical sources of diplomatic history are also part of cultural history. The first part of this essay will explain some of the broader questions and motivations for

ACKNOWLEDGEMENTS: I would like to thank Brigitte Bedos-Rezak and two anonymous readers for their comments on a preliminary draft; John McNeill, for inviting me to speak in the British Archaeological Association Lecture Series, where I presented a version of this paper; and members of the BAA audience for their responses, especially Lloyd de Beer, Sandy Heslop, and Nigel Ramsay.

ABBREVIATIONS: AN = Paris, Archives nationales de France; ASV = Rome, Archivio segreto Vaticano; $\mathrm{BL}=$ London, British Library; TNA $=$ Kew, The National Archives of the United Kingdom; ANTT = Lisbon, Arquivo nacional da Torre do Tombo.

${ }^{1}$ See Watkins 'New Diplomatic History' (calling for 'a multidisciplinary reevaluation of one of the oldest, and traditionally one of the most conservative, subfields in the modern discipline of history: the study of premodern diplomacy', p. 1). I will use the American term, 'diplomatics', to refer to the field of documentary studies, rather than the British 'diplomatic', reserving the latter here as the adjectival form of 'diplomacy'. 
its choice of method and sources; the second part will offer some specific illustrative examples of that method in practice.

This approach brings some of the conceptual framework that inspires the expanded field of diplomacy back to the center of that field, returning with new eyes to some of the most traditional subject matter of 'Old' diplomatic history, and integrating that perspective with the analytic practices of art history, visual culture, and the study of material texts. In doing so, that analysis also draws from longstanding practices of the so-called auxiliary sciences of diplomatics and palaeography, as well as some of the intellectual innovations of their recent practitioners. Scholars of diplomatics have always devoted attention to the material aspects of their documents, while palaeographical literature by definition concerns itself with the visual culture of letter-forms, developing a specific vocabulary for their description; in both cases, the conceptual and theoretical implications of these methods are increasingly explicitly voiced..$^{2}$

The analysis of medieval treaty documents also contributes to the themes of this special issue on both a straightforwardly practical as well as a more conceptual level. Ratifications constitute clear instances of exchanged impressions in the most literal sense: through these documents, which formally conclude diplomatic negotiations, two chanceries exchange impressions of their seals of central government. More broadly,

2 See especially: Rück, 'Die Urkunde als Kunstwerk'; Guyotjeannin et al., Diplomatique; Rück, ed., Graphische Symbole; Bedos-Rezak, 'Medieval Identity'; Derolez, Palaeography; Webber, 'l'Écriture'; Parkes, Hands Before Our Eyes; Bedos-Rezak, 'Cutting Edge'; Barret et al., 'Introduction'. 
though, the examination of these documents explicitly flags a critical question about the role of objects in the globalizing process. If one significant framework for conceptualizing that process is the exchange, and therefore agreed investment of value in particular objects—such as silk, porcelain, and of course silver and gold, 'intrinsically the most useless of metals'-administrative documents number among those objects, and played a role in the context of territorial expansion both within the West Eurasian system and beyond it. ${ }^{3}$ The value of documents, too, is constructed rather than inherent; like gold, their principal value relies on status by mutual or multilateral consent.

However there is no such thing as a pure document-no documentary bullion, as it were. Even relatively closely situated polities like the kingdoms of Western Europe, at the level of close visual and textual analysis, often had very different documentary conventions. It is here that such close analysis of a small number of written objects can contribute to the broader discussion about how objects more generally participated in the globalizing process. How chanceries managed to participate in a shared system of diplomacy, conducted in part through these objects, calls attention to its problematic aspects, and also demonstrates some material and conceptual practices of resolution.

The analyses in the second part of this essay therefore concentrate on a small number of examples of a particular class of document: late-medieval treaty ratifications exchanged by the English royal chancery with the kingdoms of Portugal and France, for which

\footnotetext{
${ }^{3}$ Belich et al., Prospect, esp. Introduction pp. 3-10, 14-22 (quoting pp. 7-8). Bartlett, Making of Europe; Burns, 'Notaries'.
} 
ratification documents survive on both sides. This material is revealing for specific reasons. In the first instance, these documents operate along well-established lines. By the fourteenth and fifteenth centuries, documentary practices of all kinds already had a very long history, and furthermore the textual, visual, and material conventions of charter production were relatively firmly fixed in chanceries across Europe. ${ }^{4}$ Chanceries shared some, but by no means all of these conventions with one another. England, France, and Portugal, which all had developed systems of documentary production, but their chanceries issued very different kinds of charters from one another. These charters project authority, and therefore are able to exert control within their jurisdictions, and function through their own series of textual, visual, and material conventions. Such systems of well-established conventions therefore allow for a clear examination of how chanceries respond when pushed by circumstances to be self-conscious about those conventions.

\footnotetext{
4 On lay documentary literacy before and c.1200, see recently in particular: Carlin and Crouch, Lost Letters; Brown et al., Documentary Culture. For the developement of English documentary hands, see Webber, 'L'Écriture'. For comparative studies of several royal chanceries in the thirteenth to fifteenth centuries, see the essays collected in Marques, Diplomatique royale; for comments on the value of the comparative study of administrative records and practices during the same period, see Bombi, 'Petitioning between England and Avignon', pp. 65-67. In addition to those chanceries discussed in this essay, the Castilian chancery system is a particularly good example of a well-developed, standardized hierarchy of documentation; for all aspects of the privilegio rodado, its highest grade of document, see Villar Romero, Privilegio y signo rodado, especially pp. 14-18, 22; for their form and significance in particular, see Borrero Fernández, Sevilla, pp. 17-47; for their place in the documentary hierarchy of late-medieval Castile, see Ostos Salcedo and Sanz Fuentes, 'Corona de Castilla'; for reproductions of examples, with detailed catalogue entries, see Prado, Documento pintado, nos 1-7; for a recent discussion of their origins, see Sánchez González, 'Privilegios rodados', pp. 369-74.
} 
The system of diplomacy that produced treaty documents had also been fairly firmly established by the thirteenth century. ${ }^{5}$ Treaty documents generally assumed a double nature: articles of agreement, negotiated and sealed by representatives; and ratifications, sealed and exchanged by the parties themselves. The relative logistical standardization of the diplomatic process, however, did not extend to a material standardization of its products. Diplomatic charters themselves remained idiosyncratic, varied attempts at a lingua franca of visual communication. What emerged may differ each time with respect to visual detail, but they share an underlying structural similarity: the eventual document manifests a kind-of visible negotiation, the process of realizing a mutually authentic object.

The English royal chancery can offer some particularly suggestive examples. In the first place, England's documentary culture differed from that of much of continental Europe in an important respect: although notaries had by this time long since gained a foothold there, England remained the 'land of the seal'. ${ }^{6}$ Notarial instruments never became as widespread, nor did notaries ever play as central an administrative and even social role,

\footnotetext{
${ }^{5}$ See Queller, Ambassador, pp. ix, 27-29; Chaplais, 'English Diplomatic Documents to the End of Edward III's Reign'; Chaplais, 'English Diplomatic Documents, 1377-99', p. 21. Recent studies challenge some aspects of the diplomacy narrative: see for example Black, Diplomacy, especially pp. 43-44, who critiques what he sees as a 'Whiggish' bent in diplomatic history, particularly its traditional account of 'bureaucratic processes, notably systematization'. However the focus of these criticisms is more on teleologically charged - and questionable - contrasts between medieval and early modern, rather than those between the central and the later Middle Ages. For a better previous discussion of fourteenth- and fifteenth-century developments, see Guenée, Les états, pp. 216-17.

${ }^{6}$ Cheney, Notaries Public; Zutshi, 'Notaries Public'; Clanchy, Memory, pp. 299-300, 305-309.
} 
as they had for centuries in the notarial cultures of southern Europe. ${ }^{7}$ England's diplomatic correspondence therefore demonstrates a chancery's approach to negotiating such a significant difference. English diplomatic practice has also been particularly wellstudied, most notably by Pierre Chaplais, who published many documents that now invite analysis from new perspectives. Most relevant here is his English Medieval Diplomatic Practice, particularly the second volume of facsimiles and commentaries. ${ }^{8}$ Much understanding of how diplomatic encounters actually worked depends on his research, but he himself notes that the facsimile volume pays less attention to treaties than he would have wished, given the difficulties involved in their reproduction. Where he does discuss them, or their subsidiary documents, "particular attention has been paid to the formulae used and to the handwriting, in an attempt to ascertain the part played by English and foreign clerks in the drafting and engrossing of the originals under consideration'. ${ }^{9}$

These documents could also be approached in a way that is interpretive rather than deductive. Chaplais's efforts to deduce the choreography of a document's production — 'the part played by English and foreign clerks' - equally extend to other elements of the documents' material character, such as sealing, seal attachment, and decoration. He

\footnotetext{
${ }^{7}$ For notarial practice in southern Europe and more generally, see e.g. Petrucci, Notarii; Reyerson and Salata, Medieval Notaries; Burns, 'Notaries'. For Portugal in particular, see Gomes, 'Notariado'.

${ }^{8}$ Chaplais, English Medieval Diplomatic Practice (hereafter EMDP), II; see also English Diplomatic Practice in the Middle Ages, and his catalogue of Diplomatic Documents Preserved in the Public Record Office.

${ }^{9}$ Chaplais, EMDP, II, 5.
} 
aims to understand the specific logistics of diplomacy, down to the very moments when and where pen touched parchment and metal touched wax - the realities of human bodies in space. To this end, he looks to untangle the roles of the representatives of each communicating party; he therefore uses formal analysis as a diagnostic for a creator's origin. However, there remains the expressive possibility of choice. Scribes, artists, and authors often adopt unfamiliar languages and conventions, both verbal and visual, as is already well-known from a diverse range of late-medieval examples, from scribes in north-western Europe to painters in Nasrid Granada. ${ }^{10}$ The creative imitation of 'foreign' styles can work across time as well as space, as is perhaps even better-known in both palaeographical and art-historical scholarship. ${ }^{11}$ The departure from routine chancery practices allows for the observation and interpretation of active choice. ${ }^{12}$

The documents of diplomacy demand such active choice. The vast majority of charters produced by a chancery of central government are instruments of domestic sovereignty, while diplomatic documents demand the creation of a charter with recognizable authority

\footnotetext{
${ }^{10}$ For a palaeographical study, see Mynors, 'T. Werken'; for the paintings in the Alhambra Hall of Justice, see: Dodds, 'Sala de Justicia'; Robinson and Pinet, Courting the Alhambra.

${ }^{11}$ See, for example: Parkes, 'Archaizing Hands'; Carqué, Stil und Erinnerung.

12 For arguments emphasizing models of active choice rather than influence, in both art history and diplomatics, see: Marrow, 'Dutch Manuscript Painting in Context', pp. 53-54 ('Consideration of artistic interchange and inspiration are plentiful... but far too many of these considerations are limited to enumerations of artistic influence, and neglect the more important questions of how and especially why specific visual traditions were emulated... why specific artistic or textual traditions were deemed worthy or appropriate for imitation'); Zutshi, 'Papal Chancery', p. 201.
} 
in (at least) two contexts. ${ }^{13}$ A document that crossed contemporary jurisdictions needed to work in the visual language of the recipient as well as the issuing chancery; often, to address recipients of equal or higher status, rather than its sigillant's own subjects; and finally, to evoke authority beyond the sigillant's own jurisdiction. This brief required discrimination among those aspects of a charter that universal as opposed to local force, but also those that relate specifically to the act of communication, as opposed to the exercise of executive power. As authentic charters operating outside their native jurisdictions, treaty ratifications required their creators to devise a visual language that transcended the authority of the very chanceries that issued them: in other words, to create a 'diplomatic aesthetic'.

\section{Two Examples: Windsor and Troyes}

Late-medieval treaty ratifications structurally recall the more elevated public instruments issued in the name of a territory's ruler to its subjects, generally following the format of the highest grades of document: royal charters, privileges, or letters patent. This was by no means an obvious development or the only option. Some of the earliest treaty documents took the form of chirographs - duplicate agreements written on the same parchment, and then divided into a copy for each party—such as several from the twelfth-

13 A problematic word and concept even for the analysis of modern nation-states; however a clarified definition of the term is useful here: see Krasner, Sovereignty, pp. 3-4: a ruler's 'domestic sovereignty' can be understood as 'the formal organization of political authority within the borders of their own polity'. Of course 'state' itself is a contentious term for medieval polities; see recently Taylor, Shape of the State, pp. $2-3$. 
century, recording alliances between England and Flanders. ${ }^{14}$ The material nature of a chirograph therefore suggests an occasion of mutual contact, even if a fictive one. The inscription of two copies of the text, on what is initially the same sheet, reinforces the document's symbolic connection to presence and performance, to an oath taken in person, in which both parties meet face-to-face. By contrast, the form of later ratification documents suggests absence — or rather, presence through representation-even when their texts specifically call for oath-taking. Each party confirms, in his own name, the articles agreed by representatives, in a document where he is represented by his seal.

In the case of the Treaty of Windsor, documents survive for ratifications issued by both João I of Portugal (r. 1385-1433) and Richard II of England (r. 1377-1399), along with Articles of Agreement sealed by the two Portuguese proctors. ${ }^{15}$ Both Richard's ratification and João's appear as royal charters of confirmation, but both look very different from those more typically issued in their names. João's in particular looks unlike any other document issued by his chancery in script or format-in everything except the sealing (figures 1-3). In fact, the charter itself was written in Richard's chancery, then signed, notarized, and sealed in Portugal before its return to England (figure 4). The two

\footnotetext{
14 TNA E 30/1-3, 5. See Chaplais, Diplomatic Documents, I, nos 1-3, 7; Chaplais, EMDP, I.ii, no. 243, and II, no. 1.

15 TNA E 30/311; ANTT Gavetas, gav. 18, mç. 3, n ${ }^{\circ}$ 25; TNA E 30/310. The alliance involved complex and extended negotiations, including several diplomatic missions and an earlier ratification by Richard, now ANTT gav. 18, mç. $1, \mathrm{n}^{\circ} 3$. Chaplais suggests João rejected the latter because it lacked the oath clause demanded by his own ratification document, emphasizing however that this remains 'a matter for speculation'. For the documents associated with the Treaty, see Rymer, Foedera, VII, 515-23, 561-62; Rego, Gavetas, VIII, 2-10, 312-320; Russell, English Intervention, pp. 414-15, 493 n. 5, 515-18, 527-28, 547-48; Chaplais, EMDP, I.ii, 522-27; Trowbridge, 'Unparalleled Alliance' (with excellent color images of some of the documents).
} 
ratifications were therefore prepared under the same direction, and mirror each other in design.

At first glance, not surprisingly, Richard's ratification looks more like a typical product of his chancery: written in a relatively constructed hand, on parchment; originally sealed with the Great Seal, attached on red and green braided cords; and with the name of the supervising clerk, Burton, inscribed in the lower right-hand corner (figures 5-6). It begins with the same language as an inspeximus charter; that is, a charter that declares he has inspected and confirmed an earlier charter, a form often used to validate privileges granted by predecessors. Here, the peace treaty is the confirmed document, initially incorporated smoothly into what would have been a common formula for English documents. And yet ultimately there are differences to this formula that go beyond the content of the charter confirmed - if the first line is familiar, the last is not. The ratification is dated the twenty-fourth day of February, A.D. 1387, and in the eleventh year of Richard's reign, where usually only the regnal year would have appeared. So the text combines its own chancery's dating system, which draws its meaning from the history of royal power, with the universal chronology of sacred history. The document also includes a validation clause, which signals its unusual methods and signs of authentication: 'In witness whereof, we have commanded our present letters to be written here-within into the form of a public instrument by a notary public, and to be proclaimed; and we have had it confirmed by the affixing of our Great Seal'. ${ }^{16}$ In addition to the Great

${ }^{16}$ In cuius rei testimonium presentes literas nostras in formam publici instrumenti per notarium publicum infrascriptam fieri et publicari mandavimus nostrique sigilli magni fecimus appensione muniri 
Seal, then, Richard's charter also bears a notarial sign and attestation. With this, the chancery has merged an English confirmation document into a hybrid record, imbricating the different practices of author and recipient, and the impressed and inscribed image as modes of validation.

Below the main text of the document, in darker ink, is the notarial mark and attestation of John de Bouland (figure 7). He is the same notary whose mark appeared on treaty's Articles of Agreement (figure 8), as well as on other documents he attested. ${ }^{17}$ Although his attestation notes that he holds his position of notary public by apostolic authority, this signum incorporates imagery that is heraldic rather than sacral: a crowned hart in a diamond, with three fleur-de-lis terminals and a lower expanded terminal bearing his name; compare, for example, the notarial sign on the Portuguese ratification (figure 4). ${ }^{18}$ The full signum is visible on the Articles of Agreement, while the plica of the ratification partially obscures it (along with the last line of the attestation), as the execution of the two forms of authentication followed the order described in the document: notarial mark and attestation; folding; sealing with the Great Seal. Notarial practices had a far more longstanding and important place in Portuguese documentation than in English practice; although there, too, these changed and developed over the course of this period, particularly the complex relationship between the ecclesiastical and lay public spheres. ${ }^{19}$

\footnotetext{
${ }^{17}$ Several documents with his sign are now in Chancery Miscellanea, TNA C 270/25.

${ }^{18}$ Compare also the 'seings-ostensoirs' discussed in Fraenkel, Signature, pp. 165-68, 170-72.

${ }^{19}$ Gomes, 'Notariado', see especially comments p. 247.
} 
Yet Portuguese royal charters did not conventionally bear notarial attestations, either; rather, they bore the king's seal and sign manual. So Richard's ratification does not in fact mimic precisely the conventions of its recipient chancery, either.

However, on the structural level of representational mode-rather than specific represented signs - the document does conform to the conventions of Portuguese royal charters, in that it has both inscribed and impressed signs of authentication. This too represents a departure from the English royal chancery's usual process: not only notarial practices, but graphic symbols more generally figure far less in English documents than in those of continental Europe. ${ }^{20}$ So in this final treaty ratification, the chancery signifies validity both within and beyond its own jurisdiction through the creation an amalgamated charter: textually an inspeximus by Letters Patent, formally a notarized royal charter; to be confirmed (muniri) by the impression of the Great Seal, but proclaimed (publicari) through its inscription as a public instrument. In this instance, the 'diplomatic aesthetic' has produced neither an English nor a Portuguese document, but one that invokes an idea of common authority. Indeed, within England, the areas in which notarial practices were most developed were matters that involved foreigners; ecclesiastical circles; and curial litigation. ${ }^{21}$ This is clearly an example of the first case, but the last may be relevant here as well: the presence of a notarial attestation suggests universality in part through its allusion to an overarching sovereignty.

\footnotetext{
${ }^{20}$ See Sayers, 'Land of Chirograph, Writ, and Seal'.

${ }^{21}$ Cheney, Notaries, see especially pp. 17, 22, 40, 52.
} 
Ratification documents for the Treaty of Troyes also survive from both sides, and these again take the form of large royal charters and letters patent. ${ }^{22}$ The French document kept in the English Exchequer Treasury of Receipt is written in French a current hand, leaving no vertical space for an initial; rather, the scribe has left spaces within the top line alone (figure 9). In these spaces, the words Charles and Perpetuelle appear in a large gothic display script, with intricate strapwork composing the back of the $\mathbf{C}$, as well as decorating ascenders throughout the top line. Within the body of the document, a more subdued display script calls attention to the initial words of clauses. The document is then sealed in green wax on red and green silk cords (figure 10). For the English ratification from the French Trésor des chartes, the document's scribe writes in Latin and adopts a more constructed treatment of the script (figure 11-12). Here, too, the initial words of the treaty's clauses stand out in textualis display script, one line high, and space in the top line has been left for the king's name, as well as for the first letters of each word in the royal style, and the A in Ad perpetuam rei memoriam. The king's name written in gothic display script, about two lines high, fills this space, along with penwork initials to the royal style, a penwork initial $\mathbf{A}$ - a fictive scroll in grisaille - about four lines high, and a few cadels of the same height. Here the scribe has left space for an initial letter, of five lines with an outward curve at the right to accommodate the bow of the $\mathbf{H}$ in Henricus;

22 TNA E 30/4111; AN AE/II/254. See Rymer, Foedera; Chaplais, EMDP, I.ii, 629-36; Danbury, 'Propaganda', p. 97. As with the Windsor treaty, several ratification documents survive, but in the case of Troyes these are multiples of the same exemplars (see Chaplais, pp. 629, 635); those discussed here are the definitively sealed engrossments in each royal treasury. 
the elaborate letter, in ink alone but very fine, more than fills this space, extending out into the upper and left margins, as well as the top line of the text space. The initial has reserved decoration of three fleurs-de-lis in the backstroke, and of three lions, modeled in grisaille, in the bow. A crown surrounds the top of the letter, inscribed fides $\mid$ pax $\mid$ iusticia across the band. The document has then been sealed with the Great Seal in dark green wax, attached on a braided cord of brown silk (figure 11).

Although the conventions of French and English documents correspond more closely than English and Portuguese ones, this charter is just as idiosyncratic as the Windsor ratification, if in a very different way. Some of its visual features resemble charters and letters patent issued by the chancery to domestic recipients at around the same time: the seal itself; the wax color of the sealing (although not the color of the cords); and the decorative cadels. Some of the decoration has domestic analogues as well: for example, a charter of incorporation issued to the Merchant Taylors' Company in 1408, with penflourishing to the $\mathbf{H}$ of Henricus, which is then surmounted by a crown bearing the legend Souereyne - similar to that on the Troyes ratification, if less elaborate. ${ }^{23}$ However the script differs, identified by Chaplais as 'an English ("Secretary") hand'. ${ }^{24}$ It therefore has some features (single-compartment $\mathbf{a}$, looped ascender on $\mathbf{d}, \mathbf{g}$ as a bucket rather than a figure-8) more reminiscent of a formal French document, including display script for initial words of clauses rather than scribal elaboration of their initial letters, a pattern not

\footnotetext{
${ }^{23}$ Fry and Sayle, Charters, n.p.: full reproduction, accidentally captioned as the 1503 charter.

${ }^{24}$ Chaplais, EMDP, I.ii, 629.
} 
normally adopted by the English chancery at this stage. Here, the negotiated aesthetic emerges not from competing modes of validation, but from competing concepts of design.

\section{Letterhead and 'extraordinary fireworks'}

Diplomacy in general, and treaties in particular, perennially involve the construction of authority through cultural forms - ceremonies, oaths, exchanges of gifts-which have performance, linguistic, visual, and material elements. These cultural forms have included everything from elaborate ritual, to exchanged works of art, to artists as diplomats or as diplomatic gifts themselves, to staged encounters with architecture and landscape..$^{25}$ Like many of the most famous diplomatic gifts of portraiture, late-medieval treaty ratifications also allow for the exchange of the royal image - in the form of a seal. And furthermore, their 'diplomatic aesthetic' offers a possible framework for understanding the broader material and visual culture of diplomacy. One can also see them as the nuclei of spectacular ceremonies, the permanent fragments of larger, lost performances. A much later account of the Russian ambassador's 1662 delegation to London vividly evokes such a setting: the ambassador's 'retinue', with

\footnotetext{
${ }^{25}$ For ceremonial, see Queller, Office of Ambassador, pp. 188-208, and Roosen, 'Early Modern Diplomatic Ceremonial'. For art as diplomatic gift in Byzantium: Cormack, 'But is it Art?'; Muthesius, 'Silken Diplomacy'; Lowden, 'Luxury Book'; Cutler, 'Significant Gifts'; Hilsdale, Byzantine Art and Diplomacy (with extensive further bibliography). Art as a diplomatic gift in early modern western Europe: Bodart, 'Enjeux'; Colantuono, 'Mute Diplomat'; Sowerby, 'Memorial'. Artist as gift: Kim, 'Gentile in Red'; staged encounters: Berger and Hedin, Diplomatic Tours in the Gardens of Versailles, pp. 25-30, 68-69, for visiting diplomats from Spain, Russia, Morocco, Algeria, Genoa, and Tripoli.
} 
their caps of fur, tunics, richly embroidered with gold and pearls, made a glorious show. The King being seated under a canopy in the Banqueting-house, the Secretary of the Embassy went before the Ambassador in a grave march, holding up his master's letters of credence in a crimson taffeta scarf before his forehead. The Ambassador then delivered it with a profound reverence to the King, who gave it to our Secretary of State: it was written in a long and lofty style. Then came in the presents borne by 165 of his retinue... These borne by so long a train rendered it very extraordinary. Wind music played all the while in the galleries above. ${ }^{26}$

Grand ceremonies could also attend the 'conclusion or proclamation of a treaty': for example, a fifteenth-century Venetian source recording one with about forty boats adorned with heraldry, as well as trumpet-music, 'extraordinary fireworks', bonfires, processions, 'splendid' costumes, and 'pageants and mysteries'. ${ }^{27}$

The importance of these material and visual aspects of diplomatic negotiation can be implicit even in analytic literature that at first seems far-removed from cultural history. For example, a recent study of international law begins by illustrating two of the subject's fundamental questions - Why do States comply with international law, and Why should States comply with international law? — with a 'domestic analogy':

\footnotetext{
${ }^{26}$ Diary of John Evelyn, I, 366-67; quoted in Roosen, 'Early Modern Diplomatic Ceremonial', pp. 467-68.

${ }^{27}$ Queller, Office of Ambassador, 190, 198-200, 209-210. This ceremonial emphasis relates closely to his thesis about ratification documents themselves; namely, that they were not in and of themselves inevitably necessary, if the negotiating representatives had full power to conclude.
} 
Suppose that I, as a university professor, lend a book to a student. The book is not returned, and I ask for it back. If it is still not returned, despite increasingly urgent informal requests, I might write to the student on University notepaper. $[\ldots]$ the shift into the University context increases my power as against that of the student [...] [and] shifts in the context of the dispute, in the factors and types of argument that are relevant, and the relative power of me and of the student, have been effected through the use of language. [...] it is by no means the case that the persuasive power of the law depends upon the immediate availability of some means of enforcement. ${ }^{28}$

In fact, not all of the shifts in this scenario are effected through the use of language; or rather, of language in isolation from its material manifestation. The analogy begins with a visual example — the University notepaper. This is a revealing choice, as visual language often plays as central a role in encounters which, though they pre-date international law as such, share its salient feature of evoking authority in the absence of unambiguous sovereignty. The analysis of diplomacy's central material texts—-looking at these, too, as cultural objects - tests how writing practices function under conceptual pressure.

${ }^{28}$ Lowe, International Law, pp. 18, 29-30. 


\section{Medieval Treaties and the Diplomatic Aesthetic}

\section{Jessica Berenbeim}

\section{Diplomacy and textual objects}

This essay brings two strands of scholarship into conversation with one another: the New Diplomatic History and the study of material texts as visual culture. What follows examines a significant point of contact for these two discussions: the documents of diplomacy, and more specifically, treaty ratifications of the later Middle Ages. A central premise of New Diplomatic History involves an understanding of diplomacy as an expanded field - in other words, there is more to diplomacy than treaties. ${ }^{1}$ As this analysis will suggest, there is also more to treaties themselves. Letters of procuration, articles of agreement, and treaty ratifications all have allusive and symbolic elements, and even these most canonical sources of diplomatic history are also part of cultural history. The first part of this essay will explain some of the broader questions and motivations for

ACKNOWLEDGEMENTS: I would like to thank Brigitte Bedos-Rezak and two anonymous readers for their comments on a preliminary draft; John McNeill, for inviting me to speak in the British Archaeological Association Lecture Series, where I presented a version of this paper; and members of the BAA audience for their responses, especially Lloyd de Beer, Sandy Heslop, and Nigel Ramsay.

ABBREVIATIONS: AN = Paris, Archives nationales de France; ASV = Rome, Archivio segreto Vaticano; $\mathrm{BL}=$ London, British Library; TNA $=$ Kew, The National Archives of the United Kingdom; ANTT = Lisbon, Arquivo nacional da Torre do Tombo.

${ }^{1}$ See Watkins 'New Diplomatic History' (calling for 'a multidisciplinary reevaluation of one of the oldest, and traditionally one of the most conservative, subfields in the modern discipline of history: the study of premodern diplomacy', p. 1). I will use the American term, 'diplomatics', to refer to the field of documentary studies, rather than the British 'diplomatic', reserving the latter here as the adjectival form of 'diplomacy'. 
its choice of method and sources; the second part will offer some specific illustrative examples of that method in practice.

This approach brings some of the conceptual framework that inspires the expanded field of diplomacy back to the center of that field, returning with new eyes to some of the most traditional subject matter of 'Old' diplomatic history, and integrating that perspective with the analytic practices of art history, visual culture, and the study of material texts. In doing so, that analysis also draws from longstanding practices of the so-called auxiliary sciences of diplomatics and palaeography, as well as some of the intellectual innovations of their recent practitioners. Scholars of diplomatics have always devoted attention to the material aspects of their documents, while palaeographical literature by definition concerns itself with the visual culture of letter-forms, developing a specific vocabulary for their description; in both cases, the conceptual and theoretical implications of these methods are increasingly explicitly voiced..$^{2}$

The analysis of medieval treaty documents also contributes to the themes of this special issue on both a straightforwardly practical as well as a more conceptual level. Ratifications constitute clear instances of exchanged impressions in the most literal sense: through these documents, which formally conclude diplomatic negotiations, two chanceries exchange impressions of their seals of central government. More broadly,

2 See especially: Rück, 'Die Urkunde als Kunstwerk'; Guyotjeannin et al., Diplomatique; Rück, ed., Graphische Symbole; Bedos-Rezak, 'Medieval Identity'; Derolez, Palaeography; Webber, 'l'Écriture'; Parkes, Hands Before Our Eyes; Bedos-Rezak, 'Cutting Edge'; Barret et al., 'Introduction'. 
though, the examination of these documents explicitly flags a critical question about the role of objects in the globalizing process. If one significant framework for conceptualizing that process is the exchange, and therefore agreed investment of value in particular objects—such as silk, porcelain, and of course silver and gold, 'intrinsically the most useless of metals'-administrative documents number among those objects, and played a role in the context of territorial expansion both within the West Eurasian system and beyond it. ${ }^{3}$ The value of documents, too, is constructed rather than inherent; like gold, their principal value relies on status by mutual or multilateral consent.

However there is no such thing as a pure document-no documentary bullion, as it were. Even relatively closely situated polities like the kingdoms of Western Europe, at the level of close visual and textual analysis, often had very different documentary conventions. It is here that such close analysis of a small number of written objects can contribute to the broader discussion about how objects more generally participated in the globalizing process. How chanceries managed to participate in a shared system of diplomacy, conducted in part through these objects, calls attention to its problematic aspects, and also demonstrates some material and conceptual practices of resolution.

The analyses in the second part of this essay therefore concentrate on a small number of examples of a particular class of document: late-medieval treaty ratifications exchanged by the English royal chancery with the kingdoms of Portugal and France, for which

\footnotetext{
${ }^{3}$ Belich et al., Prospect, esp. Introduction pp. 3-10, 14-22 (quoting pp. 7-8). Bartlett, Making of Europe; Burns, 'Notaries'.
} 
ratification documents survive on both sides. This material is revealing for specific reasons. In the first instance, these documents operate along well-established lines. By the fourteenth and fifteenth centuries, documentary practices of all kinds already had a very long history, and furthermore the textual, visual, and material conventions of charter production were relatively firmly fixed in chanceries across Europe. ${ }^{4}$ Chanceries shared some, but by no means all of these conventions with one another. England, France, and Portugal, which all had developed systems of documentary production, but their chanceries issued very different kinds of charters from one another. These charters project authority, and therefore are able to exert control within their jurisdictions, and function through their own series of textual, visual, and material conventions. Such systems of well-established conventions therefore allow for a clear examination of how chanceries respond when pushed by circumstances to be self-conscious about those conventions.

\footnotetext{
4 On lay documentary literacy before and c.1200, see recently in particular: Carlin and Crouch, Lost Letters; Brown et al., Documentary Culture. For the developement of English documentary hands, see Webber, 'L'Écriture'. For comparative studies of several royal chanceries in the thirteenth to fifteenth centuries, see the essays collected in Marques, Diplomatique royale; for comments on the value of the comparative study of administrative records and practices during the same period, see Bombi, 'Petitioning between England and Avignon', pp. 65-67. In addition to those chanceries discussed in this essay, the Castilian chancery system is a particularly good example of a well-developed, standardized hierarchy of documentation; for all aspects of the privilegio rodado, its highest grade of document, see Villar Romero, Privilegio y signo rodado, especially pp. 14-18, 22; for their form and significance in particular, see Borrero Fernández, Sevilla, pp. 17-47; for their place in the documentary hierarchy of late-medieval Castile, see Ostos Salcedo and Sanz Fuentes, 'Corona de Castilla'; for reproductions of examples, with detailed catalogue entries, see Prado, Documento pintado, nos 1-7; for a recent discussion of their origins, see Sánchez González, 'Privilegios rodados', pp. 369-74.
} 
The system of diplomacy that produced treaty documents had also been fairly firmly established by the thirteenth century. ${ }^{5}$ Treaty documents generally assumed a double nature: articles of agreement, negotiated and sealed by representatives; and ratifications, sealed and exchanged by the parties themselves. The relative logistical standardization of the diplomatic process, however, did not extend to a material standardization of its products. Diplomatic charters themselves remained idiosyncratic, varied attempts at a lingua franca of visual communication. What emerged may differ each time with respect to visual detail, but they share an underlying structural similarity: the eventual document manifests a kind-of visible negotiation, the process of realizing a mutually authentic object.

The English royal chancery can offer some particularly suggestive examples. In the first place, England's documentary culture differed from that of much of continental Europe in an important respect: although notaries had by this time long since gained a foothold there, England remained the 'land of the seal'. ${ }^{6}$ Notarial instruments never became as widespread, nor did notaries ever play as central an administrative and even social role,

\footnotetext{
${ }^{5}$ See Queller, Ambassador, pp. ix, 27-29; Chaplais, 'English Diplomatic Documents to the End of Edward III's Reign'; Chaplais, 'English Diplomatic Documents, 1377-99', p. 21. Recent studies challenge some aspects of the diplomacy narrative: see for example Black, Diplomacy, especially pp. 43-44, who critiques what he sees as a 'Whiggish' bent in diplomatic history, particularly its traditional account of 'bureaucratic processes, notably systematization'. However the focus of these criticisms is more on teleologically charged - and questionable - contrasts between medieval and early modern, rather than those between the central and the later Middle Ages. For a better previous discussion of fourteenth- and fifteenth-century developments, see Guenée, Les états, pp. 216-17.

${ }^{6}$ Cheney, Notaries Public; Zutshi, 'Notaries Public'; Clanchy, Memory, pp. 299-300, 305-309.
} 
as they had for centuries in the notarial cultures of southern Europe. ${ }^{7}$ England's diplomatic correspondence therefore demonstrates a chancery's approach to negotiating such a significant difference. English diplomatic practice has also been particularly wellstudied, most notably by Pierre Chaplais, who published many documents that now invite analysis from new perspectives. Most relevant here is his English Medieval Diplomatic Practice, particularly the second volume of facsimiles and commentaries. ${ }^{8}$ Much understanding of how diplomatic encounters actually worked depends on his research, but he himself notes that the facsimile volume pays less attention to treaties than he would have wished, given the difficulties involved in their reproduction. Where he does discuss them, or their subsidiary documents, "particular attention has been paid to the formulae used and to the handwriting, in an attempt to ascertain the part played by English and foreign clerks in the drafting and engrossing of the originals under consideration'. ${ }^{9}$

These documents could also be approached in a way that is interpretive rather than deductive. Chaplais's efforts to deduce the choreography of a document's production — 'the part played by English and foreign clerks' - equally extend to other elements of the documents' material character, such as sealing, seal attachment, and decoration. He

\footnotetext{
${ }^{7}$ For notarial practice in southern Europe and more generally, see e.g. Petrucci, Notarii; Reyerson and Salata, Medieval Notaries; Burns, 'Notaries'. For Portugal in particular, see Gomes, 'Notariado'.

${ }^{8}$ Chaplais, English Medieval Diplomatic Practice (hereafter EMDP), II; see also English Diplomatic Practice in the Middle Ages, and his catalogue of Diplomatic Documents Preserved in the Public Record Office.

${ }^{9}$ Chaplais, EMDP, II, 5.
} 
aims to understand the specific logistics of diplomacy, down to the very moments when and where pen touched parchment and metal touched wax - the realities of human bodies in space. To this end, he looks to untangle the roles of the representatives of each communicating party; he therefore uses formal analysis as a diagnostic for a creator's origin. However, there remains the expressive possibility of choice. Scribes, artists, and authors often adopt unfamiliar languages and conventions, both verbal and visual, as is already well-known from a diverse range of late-medieval examples, from scribes in north-western Europe to painters in Nasrid Granada. ${ }^{10}$ The creative imitation of 'foreign' styles can work across time as well as space, as is perhaps even better-known in both palaeographical and art-historical scholarship. ${ }^{11}$ The departure from routine chancery practices allows for the observation and interpretation of active choice. ${ }^{12}$

The documents of diplomacy demand such active choice. The vast majority of charters produced by a chancery of central government are instruments of domestic sovereignty, while diplomatic documents demand the creation of a charter with recognizable authority

\footnotetext{
${ }^{10}$ For a palaeographical study, see Mynors, 'T. Werken'; for the paintings in the Alhambra Hall of Justice, see: Dodds, 'Sala de Justicia'; Robinson and Pinet, Courting the Alhambra.

${ }^{11}$ See, for example: Parkes, 'Archaizing Hands'; Carqué, Stil und Erinnerung.

12 For arguments emphasizing models of active choice rather than influence, in both art history and diplomatics, see: Marrow, 'Dutch Manuscript Painting in Context', pp. 53-54 ('Consideration of artistic interchange and inspiration are plentiful... but far too many of these considerations are limited to enumerations of artistic influence, and neglect the more important questions of how and especially why specific visual traditions were emulated... why specific artistic or textual traditions were deemed worthy or appropriate for imitation'); Zutshi, 'Papal Chancery', p. 201.
} 
in (at least) two contexts. ${ }^{13}$ A document that crossed contemporary jurisdictions needed to work in the visual language of the recipient as well as the issuing chancery; often, to address recipients of equal or higher status, rather than its sigillant's own subjects; and finally, to evoke authority beyond the sigillant's own jurisdiction. This brief required discrimination among those aspects of a charter that universal as opposed to local force, but also those that relate specifically to the act of communication, as opposed to the exercise of executive power. As authentic charters operating outside their native jurisdictions, treaty ratifications required their creators to devise a visual language that transcended the authority of the very chanceries that issued them: in other words, to create a 'diplomatic aesthetic'.

\section{Two Examples: Windsor and Troyes}

Late-medieval treaty ratifications structurally recall the more elevated public instruments issued in the name of a territory's ruler to its subjects, generally following the format of the highest grades of document: royal charters, privileges, or letters patent. This was by no means an obvious development or the only option. Some of the earliest treaty documents took the form of chirographs - duplicate agreements written on the same parchment, and then divided into a copy for each party—such as several from the twelfth-

13 A problematic word and concept even for the analysis of modern nation-states; however a clarified definition of the term is useful here: see Krasner, Sovereignty, pp. 3-4: a ruler's 'domestic sovereignty' can be understood as 'the formal organization of political authority within the borders of their own polity'. Of course 'state' itself is a contentious term for medieval polities; see recently Taylor, Shape of the State, pp. $2-3$. 
century, recording alliances between England and Flanders. ${ }^{14}$ The material nature of a chirograph therefore suggests an occasion of mutual contact, even if a fictive one. The inscription of two copies of the text, on what is initially the same sheet, reinforces the document's symbolic connection to presence and performance, to an oath taken in person, in which both parties meet face-to-face. By contrast, the form of later ratification documents suggests absence — or rather, presence through representation-even when their texts specifically call for oath-taking. Each party confirms, in his own name, the articles agreed by representatives, in a document where he is represented by his seal.

In the case of the Treaty of Windsor, documents survive for ratifications issued by both João I of Portugal (r. 1385-1433) and Richard II of England (r. 1377-1399), along with Articles of Agreement sealed by the two Portuguese proctors. ${ }^{15}$ Both Richard's ratification and João's appear as royal charters of confirmation, but both look very different from those more typically issued in their names. João's in particular looks unlike any other document issued by his chancery in script or format-in everything except the sealing (figures 1-3). In fact, the charter itself was written in Richard's chancery, then signed, notarized, and sealed in Portugal before its return to England (figure 4). The two

\footnotetext{
14 TNA E 30/1-3, 5. See Chaplais, Diplomatic Documents, I, nos 1-3, 7; Chaplais, EMDP, I.ii, no. 243, and II, no. 1.

15 TNA E 30/311; ANTT Gavetas, gav. 18, mç. 3, n ${ }^{\circ}$ 25; TNA E 30/310. The alliance involved complex and extended negotiations, including several diplomatic missions and an earlier ratification by Richard, now ANTT gav. 18, mç. $1, \mathrm{n}^{\circ} 3$. Chaplais suggests João rejected the latter because it lacked the oath clause demanded by his own ratification document, emphasizing however that this remains 'a matter for speculation'. For the documents associated with the Treaty, see Rymer, Foedera, VII, 515-23, 561-62; Rego, Gavetas, VIII, 2-10, 312-320; Russell, English Intervention, pp. 414-15, 493 n. 5, 515-18, 527-28, 547-48; Chaplais, EMDP, I.ii, 522-27; Trowbridge, 'Unparalleled Alliance' (with excellent color images of some of the documents).
} 
ratifications were therefore prepared under the same direction, and mirror each other in design.

At first glance, not surprisingly, Richard's ratification looks more like a typical product of his chancery: written in a relatively constructed hand, on parchment; originally sealed with the Great Seal, attached on red and green braided cords; and with the name of the supervising clerk, Burton, inscribed in the lower right-hand corner (figures 5-6). It begins with the same language as an inspeximus charter; that is, a charter that declares he has inspected and confirmed an earlier charter, a form often used to validate privileges granted by predecessors. Here, the peace treaty is the confirmed document, initially incorporated smoothly into what would have been a common formula for English documents. And yet ultimately there are differences to this formula that go beyond the content of the charter confirmed - if the first line is familiar, the last is not. The ratification is dated the twenty-fourth day of February, A.D. 1387, and in the eleventh year of Richard's reign, where usually only the regnal year would have appeared. So the text combines its own chancery's dating system, which draws its meaning from the history of royal power, with the universal chronology of sacred history. The document also includes a validation clause, which signals its unusual methods and signs of authentication: 'In witness whereof, we have commanded our present letters to be written here-within into the form of a public instrument by a notary public, and to be proclaimed; and we have had it confirmed by the affixing of our Great Seal'. ${ }^{16}$ In addition to the Great

${ }^{16}$ In cuius rei testimonium presentes literas nostras in formam publici instrumenti per notarium publicum infrascriptam fieri et publicari mandavimus nostrique sigilli magni fecimus appensione muniri 
Seal, then, Richard's charter also bears a notarial sign and attestation. With this, the chancery has merged an English confirmation document into a hybrid record, imbricating the different practices of author and recipient, and the impressed and inscribed image as modes of validation.

Below the main text of the document, in darker ink, is the notarial mark and attestation of John de Bouland (figure 7). He is the same notary whose mark appeared on treaty's Articles of Agreement (figure 8), as well as on other documents he attested. ${ }^{17}$ Although his attestation notes that he holds his position of notary public by apostolic authority, this signum incorporates imagery that is heraldic rather than sacral: a crowned hart in a diamond, with three fleur-de-lis terminals and a lower expanded terminal bearing his name; compare, for example, the notarial sign on the Portuguese ratification (figure 4). ${ }^{18}$ The full signum is visible on the Articles of Agreement, while the plica of the ratification partially obscures it (along with the last line of the attestation), as the execution of the two forms of authentication followed the order described in the document: notarial mark and attestation; folding; sealing with the Great Seal. Notarial practices had a far more longstanding and important place in Portuguese documentation than in English practice; although there, too, these changed and developed over the course of this period, particularly the complex relationship between the ecclesiastical and lay public spheres. ${ }^{19}$

\footnotetext{
${ }^{17}$ Several documents with his sign are now in Chancery Miscellanea, TNA C 270/25.

${ }^{18}$ Compare also the 'seings-ostensoirs' discussed in Fraenkel, Signature, pp. 165-68, 170-72.

${ }^{19}$ Gomes, 'Notariado', see especially comments p. 247.
} 
Yet Portuguese royal charters did not conventionally bear notarial attestations, either; rather, they bore the king's seal and sign manual. So Richard's ratification does not in fact mimic precisely the conventions of its recipient chancery, either.

However, on the structural level of representational mode-rather than specific represented signs - the document does conform to the conventions of Portuguese royal charters, in that it has both inscribed and impressed signs of authentication. This too represents a departure from the English royal chancery's usual process: not only notarial practices, but graphic symbols more generally figure far less in English documents than in those of continental Europe. ${ }^{20}$ So in this final treaty ratification, the chancery signifies validity both within and beyond its own jurisdiction through the creation an amalgamated charter: textually an inspeximus by Letters Patent, formally a notarized royal charter; to be confirmed (muniri) by the impression of the Great Seal, but proclaimed (publicari) through its inscription as a public instrument. In this instance, the 'diplomatic aesthetic' has produced neither an English nor a Portuguese document, but one that invokes an idea of common authority. Indeed, within England, the areas in which notarial practices were most developed were matters that involved foreigners; ecclesiastical circles; and curial litigation. ${ }^{21}$ This is clearly an example of the first case, but the last may be relevant here as well: the presence of a notarial attestation suggests universality in part through its allusion to an overarching sovereignty.

\footnotetext{
${ }^{20}$ See Sayers, 'Land of Chirograph, Writ, and Seal'.

${ }^{21}$ Cheney, Notaries, see especially pp. 17, 22, 40, 52.
} 
Ratification documents for the Treaty of Troyes also survive from both sides, and these again take the form of large royal charters and letters patent. ${ }^{22}$ The French document kept in the English Exchequer Treasury of Receipt is written in French a current hand, leaving no vertical space for an initial; rather, the scribe has left spaces within the top line alone (figure 9). In these spaces, the words Charles and Perpetuelle appear in a large gothic display script, with intricate strapwork composing the back of the $\mathbf{C}$, as well as decorating ascenders throughout the top line. Within the body of the document, a more subdued display script calls attention to the initial words of clauses. The document is then sealed in green wax on red and green silk cords (figure 10). For the English ratification from the French Trésor des chartes, the document's scribe writes in Latin and adopts a more constructed treatment of the script (figure 11-12). Here, too, the initial words of the treaty's clauses stand out in textualis display script, one line high, and space in the top line has been left for the king's name, as well as for the first letters of each word in the royal style, and the A in Ad perpetuam rei memoriam. The king's name written in gothic display script, about two lines high, fills this space, along with penwork initials to the royal style, a penwork initial $\mathbf{A}$ - a fictive scroll in grisaille - about four lines high, and a few cadels of the same height. Here the scribe has left space for an initial letter, of five lines with an outward curve at the right to accommodate the bow of the $\mathbf{H}$ in Henricus;

22 TNA E 30/4111; AN AE/II/254. See Rymer, Foedera; Chaplais, EMDP, I.ii, 629-36; Danbury, 'Propaganda', p. 97. As with the Windsor treaty, several ratification documents survive, but in the case of Troyes these are multiples of the same exemplars (see Chaplais, pp. 629, 635); those discussed here are the definitively sealed engrossments in each royal treasury. 
the elaborate letter, in ink alone but very fine, more than fills this space, extending out into the upper and left margins, as well as the top line of the text space. The initial has reserved decoration of three fleurs-de-lis in the backstroke, and of three lions, modeled in grisaille, in the bow. A crown surrounds the top of the letter, inscribed fides $\mid$ pax $\mid$ iusticia across the band. The document has then been sealed with the Great Seal in dark green wax, attached on a braided cord of brown silk (figure 11).

Although the conventions of French and English documents correspond more closely than English and Portuguese ones, this charter is just as idiosyncratic as the Windsor ratification, if in a very different way. Some of its visual features resemble charters and letters patent issued by the chancery to domestic recipients at around the same time: the seal itself; the wax color of the sealing (although not the color of the cords); and the decorative cadels. Some of the decoration has domestic analogues as well: for example, a charter of incorporation issued to the Merchant Taylors' Company in 1408, with penflourishing to the $\mathbf{H}$ of Henricus, which is then surmounted by a crown bearing the legend Souereyne - similar to that on the Troyes ratification, if less elaborate. ${ }^{23}$ However the script differs, identified by Chaplais as 'an English ("Secretary") hand'. ${ }^{24}$ It therefore has some features (single-compartment $\mathbf{a}$, looped ascender on $\mathbf{d}, \mathbf{g}$ as a bucket rather than a figure-8) more reminiscent of a formal French document, including display script for initial words of clauses rather than scribal elaboration of their initial letters, a pattern not

\footnotetext{
${ }^{23}$ Fry and Sayle, Charters, n.p.: full reproduction, accidentally captioned as the 1503 charter.

${ }^{24}$ Chaplais, EMDP, I.ii, 629.
} 
normally adopted by the English chancery at this stage. Here, the negotiated aesthetic emerges not from competing modes of validation, but from competing concepts of design.

\section{Letterhead and 'extraordinary fireworks'}

Diplomacy in general, and treaties in particular, perennially involve the construction of authority through cultural forms - ceremonies, oaths, exchanges of gifts-which have performance, linguistic, visual, and material elements. These cultural forms have included everything from elaborate ritual, to exchanged works of art, to artists as diplomats or as diplomatic gifts themselves, to staged encounters with architecture and landscape..$^{25}$ Like many of the most famous diplomatic gifts of portraiture, late-medieval treaty ratifications also allow for the exchange of the royal image - in the form of a seal. And furthermore, their 'diplomatic aesthetic' offers a possible framework for understanding the broader material and visual culture of diplomacy. One can also see them as the nuclei of spectacular ceremonies, the permanent fragments of larger, lost performances. A much later account of the Russian ambassador's 1662 delegation to London vividly evokes such a setting: the ambassador's 'retinue', with

\footnotetext{
${ }^{25}$ For ceremonial, see Queller, Office of Ambassador, pp. 188-208, and Roosen, 'Early Modern Diplomatic Ceremonial'. For art as diplomatic gift in Byzantium: Cormack, 'But is it Art?'; Muthesius, 'Silken Diplomacy'; Lowden, 'Luxury Book'; Cutler, 'Significant Gifts'; Hilsdale, Byzantine Art and Diplomacy (with extensive further bibliography). Art as a diplomatic gift in early modern western Europe: Bodart, 'Enjeux'; Colantuono, 'Mute Diplomat'; Sowerby, 'Memorial'. Artist as gift: Kim, 'Gentile in Red'; staged encounters: Berger and Hedin, Diplomatic Tours in the Gardens of Versailles, pp. 25-30, 68-69, for visiting diplomats from Spain, Russia, Morocco, Algeria, Genoa, and Tripoli.
} 
their caps of fur, tunics, richly embroidered with gold and pearls, made a glorious show. The King being seated under a canopy in the Banqueting-house, the Secretary of the Embassy went before the Ambassador in a grave march, holding up his master's letters of credence in a crimson taffeta scarf before his forehead. The Ambassador then delivered it with a profound reverence to the King, who gave it to our Secretary of State: it was written in a long and lofty style. Then came in the presents borne by 165 of his retinue... These borne by so long a train rendered it very extraordinary. Wind music played all the while in the galleries above. ${ }^{26}$

Grand ceremonies could also attend the 'conclusion or proclamation of a treaty': for example, a fifteenth-century Venetian source recording one with about forty boats adorned with heraldry, as well as trumpet-music, 'extraordinary fireworks', bonfires, processions, 'splendid' costumes, and 'pageants and mysteries'. ${ }^{27}$

The importance of these material and visual aspects of diplomatic negotiation can be implicit even in analytic literature that at first seems far-removed from cultural history. For example, a recent study of international law begins by illustrating two of the subject's fundamental questions - Why do States comply with international law, and Why should States comply with international law? — with a 'domestic analogy':

\footnotetext{
${ }^{26}$ Diary of John Evelyn, I, 366-67; quoted in Roosen, 'Early Modern Diplomatic Ceremonial', pp. 467-68.

${ }^{27}$ Queller, Office of Ambassador, 190, 198-200, 209-210. This ceremonial emphasis relates closely to his thesis about ratification documents themselves; namely, that they were not in and of themselves inevitably necessary, if the negotiating representatives had full power to conclude.
} 
Suppose that I, as a university professor, lend a book to a student. The book is not returned, and I ask for it back. If it is still not returned, despite increasingly urgent informal requests, I might write to the student on University notepaper. $[\ldots]$ the shift into the University context increases my power as against that of the student [...] [and] shifts in the context of the dispute, in the factors and types of argument that are relevant, and the relative power of me and of the student, have been effected through the use of language. [...] it is by no means the case that the persuasive power of the law depends upon the immediate availability of some means of enforcement. ${ }^{28}$

In fact, not all of the shifts in this scenario are effected through the use of language; or rather, of language in isolation from its material manifestation. The analogy begins with a visual example — the University notepaper. This is a revealing choice, as visual language often plays as central a role in encounters which, though they pre-date international law as such, share its salient feature of evoking authority in the absence of unambiguous sovereignty. The analysis of diplomacy's central material texts—-looking at these, too, as cultural objects - tests how writing practices function under conceptual pressure.

${ }^{28}$ Lowe, International Law, pp. 18, 29-30. 